\title{
State coercion and public sector unionism in post-coup Fiji
}

\author{
Jacqueline Leckie*
}

The trade union movement played a pivotal role in the formation of the Fiji Labour Party, and later represented a potential source of organized opposition to the military regime which overthrew the Labour Government in 1987. This paper explores why the Fiji administration perceived organized labour as a threat and discusses the measures the military regime took to retain control by weakening any political role for unions. Much of the regime's energy in this respect has been directed towards the Fiji Public Service Association. Its leaders argue that the fundamental issue of trade union rights can not be guaranteed without the protection of human rights and a democratic framework in Fiji, neither of which is assured in the recently promulgated constitution.

\section{Introduction and background}

The Fiji trade union movement, the strongest expression of organized labour in the South Pacific Islands, is facing its biggest threat to its existence. This comes from the State which since May 1987 has been a military backed regime. However the State's response to trade unions should be understood within the historical context of the growing power and assertiveness of the labour movement in Fiji. This was epitomized when the Fiji Trades Union Congress (FTUC) sponsored the formation of a Fiji Labour Party (FLP) in 1985, which, along with sections of the National Federation Party (NFP), was elected as the Coalition Government in 1987.

The perception of this as a victory for labour and a change in direction from ethnic based politics is fundamental to analysing subsequent developments in Fiji. However, most discussion of the coups has failed to address adequately the importance of workers' organizations in the formation of the FLP and their significance after the coups. This paper follows on from earlier research into the history of trade unions and especially that of Fiji's most powerful union, the Fiji Public Service Association (FPSA). The threat to trade unions in Fiji can be traced through the strategies the State has adopted to weaken this union.

It could be argued that given the past importance of the FPSA to Fiji's labour movement, its survival will be an indicator of the future patterns for labour there. This

* Department of Anthropology, University of Otago. An earlier version of this paper was presented to the biennial conference of the Association of Industrial Relations Academics of Australia and New Zealand, Melboume 4-7 July 1990. I would like to thank Ian Frazer, Colin Hicks, and Pat Walsh for helpful comments, and the Fiji Public Service Association for its assistance. An Otago University Research Grant allowed me to update earlier research. 
needs to be placed against changes in the structural context of labour relations in Fiji and an assessment of why the regime has been so persistent in containing unions.

Conflict and accommodation between labour, capital and the State has been played out within various political and economic structures during the colonial and postcolonial contexts. Colonial control was based upon overt coercion sustained through direct force. In the past, as in Fiji's contemporary period, the State also exerted its dominance over the workforce through restrictive legislation, an absence of consultative and workable industrial relations mechanisms, the manipulation of ethnic divisions and appeals to traditional loyalties. Initially, such means sought to control mainly Indian migrant labour in sugar production, and regulated the entry of indigenous labour into the paid workforce (Bain, 1988). Colonial development was sharply focused along communal lines (Durutalo, 1985) which in turn reinforced the development of workers' organizations along ethnic lines (Hince, 1971). Indian migrants and their descendants continued to dominate the sugar industry where some of the first labour organizations in Fiji emerged by World War II. By then the State had also shifted from an anti-union policy to one of accommodating acceptable labour organizations. Under pressure from the British Government, the colonial administration encouraged the formation of compliant trade unions through an Industrial Associations Ordinance and the establishment of a Labour Department in 1942.

This picture presents an ethnically divided labour force during the colonial period, but on closer examination the details were far more complex. First, there was always a small but growing number of indigenous Fijians working in paid employment. Stevedoring was one such industry, where Edmund Sanday, of mixed Fijian and European descent, and Setareki Nasoki, a Fijian, attempted to form a trade union in 1916. This was opposed by capital, met by brutal repression and blocked by appeals to traditional authority (Hince, 1985). There were later attempts by Fijians to resist labour control and form trade unions (Leckie, 1991) but as Bain (1985) has demonstrated with the goldmining industry, ethnicity and the traditional hierarchy were utilized as a means of control. Secondly, in some sectors the beginnings of a mixed workforce emerged in colonial Fiji, notably in the public sector. The State's attitudes towards these unions was contradictory. For example, it encouraged the existence of ethnically divided unions, the Fijian Teachers' Association, exclusively for indigenous Fijians and the Fiji Teachers' Union, open to all ethnic groups but attracting mainly Indo-Fijians.

Unionization in the civil service took a different direction. By 1943, a multi-racial Fiji Public Servants' Association was formed, which became registered as a trade union in 1958 (Leckie, 1986). Rather than promote the formation of splinter associations, the colonial administrators were eager to see civil servants being represented by a "sensibly led main union"1 to avert the possibility of disruptive or politicized unions forming. Leadership in the FPSA came from local Europeans and Indo-Fijians, but increasingly as Fiji moved towards independence, compliant indigenous leadership was promoted (Leckie, 1986 , p.24-31) so that stability would prevail when the bureaucracy came under local political control.

This semblance of harmony overlooks the existence of serious conflict between labour, capital and the State which was reflected in industrial action and attempts by workers to organize (Leckie, 1991). Overt instances were the 1959 oilworkers' strike (Hempenstall, 1984, p.73-86) and industrial unrest within the goldmining industry during the 1950s (Bain, 1985) and by sugar workers in the late 1950s and early 1960s. These expressions of labour militancy were quietened by repression or appeals to ethnic and traditional loyalties but, in the longer term, labour unrest was contained through the

1 Correspondence from Colonial Secretary to Commissioner of Organisation and Establishments, 25 July 1968 (E60/106, Fiji National Archives). 
acceptance of power bargaining which resulted in gradual wage increases and improvements in employment and living conditions for workers.

By independence in 1970 the labour movement in Fiji did not appear to foreshadow a serious threat to the neo-colonial order. In contrast to many other colonies, Fiji lacked an identifiable nationalist movement which might have encompassed labour militancy (Munck, 1988, p.165-171). Documentation to date suggests that popular organizations such as unions were excluded from the independence negotiations, but the 1970 constitution guaranteed the right of free association.

The honeymoon was brief. Independence did not herald a decade of docile industrial relations but gave way to the emergence of a more confrontational style. New labour legislation, particularly the Trade Disputes Act 1973, sought to constrain the parameters of conflict between workers and employers. This made it very difficult for workers to take industrial action, especially in essential services, and weakened joint trade union action by outlawing solidarity strikes. The same year saw the implementation of unilateral restrictions on free collective bargaining with the Counter Inflation Act. Imposing wage and salary freezes, or non-negotiable guidelines on increases came to be a feature of industrial relations in Fiji. Lines between management and labour had been sketched in the public sector with the formation of the Public Service Commission (PSC) in 1960, but were firmly drawn in 1975 when the FPSA asserted its independence by establishing a full-time secretariat.

The first half of the 1970 s was a period of several stormy labour disputes, but by 1976 a conciliatory situation appeared to be reached with tripartism guiding wage negotiations and many other industrial relations matters. The Tripartite Forum consisted of representatives from the FTUC, the employers and government and although it opened the way to dispute solving through its Committee on Industrial Relations, increasingly unions became disillusioned as employers perceived the Forum as a vehicle for imposing restraints on wages and salaries (FPSA, Annual Report, 1978). This did not constrain the FPSA from securing an impressive record of resolving grievances and disputes in its members' favour, as well as pressing for salary rises and improved conditions.

Any illusions of a cordial relationship between civil service unions and government were soon crushed during prolonged and bitter negotiations in the early 1980s over the implementation of substantial salary increases recommended through what came to be known as the Nicol and Hurst Award. The FPSA's claims were successful, but this marked the beginning of a period of increased hostility between government and public sector unions (Howard, 1985; Leckie, 1988). When faced with much broader economic problems, especially inflation and unemployment, the State laid the cause of a unilateral wage and salary freeze in November 1984 at the doors of the FPSA. This marked the end of tripartism. This was the most direct cause of the FTUC's reassessment of its relationship with the State and its withdrawal from the Tripartite Forum. Although the boycott was only while the wage freeze remained in force, the Government responded by withdrawing recognition of the FTUC as the national union body. Other related developments, such a volunteer teachers' scheme and increased bus fares for schoolchildren led to public sector workers becoming increasingly concerted in their criticism of government policies. When workers endorsed the FTUC's call for a general strike, the Prime Minister, Ratu Mara, threatened to declare a state of emergency, bring in the army and sack civil servants (Fiji Times, 10 January 1985).

With few alternatives, in August 1985 the FTUC launched the FLP to represent the interests of workers and provide an effective opposition to the ruling Alliance Party. Until then the main opposition party was the NFP. Although it had claimed to draw on multi-ethnic and trade union support, by the mid-1980s it offered no real political alternatives and was viewed as an Indo-Fijian party. Many unionists believed that the subsequent coalition between FLP and sections of the NFP became crucial if unions were to retain the advances they had made and to extend these to other sectors of Fiji's 
workforce. Even in 1985 some unionists were convinced that the Fiji labour movement was under serious threat from the State.

Several statements from the Alliance Party and later from the instigator of the Fiji coups, Colonel Sitiveni Rabuka, attributed the formation of the FLP to the FPSA. Many of the leaders of the FLP were drawn from FPSA officials, notably Dr Timoci Bavadra, the leader of the Coalition and former president of the FPSA between 1977-1985 and Mahendra Chaudhry, general secretary of the FPSA since 1970 and Minister of Finance during the short-lived Coalition Government of 1987. Rabuka stated that:

The Fiji Public Service Association I knew, was naturally supportive of Coalition policies. After all, the Labour Party had been hatched from the Association by the new Prime Minister, Timoci Bavadra, who had been the Association President for years (Dean and Ritova, 1988, p.46).

Rabuka's biographers also state $(1988$, p.33) that the Labour Party was mainly backed by the FPSA. Certainly since the early 1980s the FPSA had become increasingly critical of the Government's policies and advocated that trade unions, particularly rank and file members, should seek to change wider economic and social inbalances in the nation (FPSA, Annual Report, 1985, p.15). While the FPSA became a cornerstone of the FLP, it did not singly launch the new party. It was founded and supported by a number of unions affiliated to the FTUC, along with representatives of other groups disenchanted by Alliance policy (Lal, 1986, p.139-157; Robertson and Tamanisau, 1988, p.18-42).

Nevertheless the link between the FPSA and the Coalition appears to have been a serious threat to entrenched and powerful interests in the public service, which had developed under Alliance rule. A major platform of Bavadra's campaign focused on accusations of corruption linking politicians, bureaucrats and private concerns (Hagan, 1987, p.13-14). The Coalition's promise to investigate this if it assumed power implied a considerable reshuffle of the civil service. Rabuka cites this as one reason for staging the coup:

The Coalition would move in their own people, and place them in prominent positions and further their political goals, and use their influence to change the directions of Fiji's political, economic and previously excellent foreign relations (Dean and Ritova, 1988, p.46).

The FPSA was considered a threat not only because of its role in the formation of the FLP but also because of its willingness to endorse the policies of a Coalition government. The FPSA had drawn attention to corruption and inappropriate government and management policies years before the FLP was formed.

Coalition plans to introduce changes in the bureaucracy and implement new social policies were shattered by the coup on 14 May 1987, but the coup did not deter the "union threat". This was partly because sections of the labour movement overtly criticized and organized opposition to the military regime. Munck $(1988$, p.176) has observed that the ability of military regimes to stabilize may be dependent on the capacity of the labour movement to restructure itself and mount a resistance campaign. During the immediate post-coup chaos, trade unions were one of the few multi-ethnic opposition groups with some kind of institutional structure, even if in most cases this was weak. The FPSA, and some, mainly white-collar unions, were exceptions. Chaudhry, quickly reinstated as general secretary of the FPSA, along with other union colleagues rapidly mustered international trade union support to put pressure on the illegal regime. At the FTUC's request cargo and passenger bans were instigated by New Zealand and Australian unions. The effects were dramatic on an island nation heavily dependent upon imports and foreign exchange generated from tourist revenue and exports (Howard, 1988, p.187190 and p.198-200). Even after the bans were lifted, unions were able to use this as a 
threat when human and especially trade union rights were being denied. This fomented the regime's hostility towards unions and especially towards Chaudhry, as he opposed the FTUC's decision to remove bans on 4 July 1987 . Chaudhry continued to rally international solidarity and to draw upon the strong links his union had with public sector unions in New Zealand and Australia and with international labour bodies such as the Postal Telegraph and Telephone International (PTTI), Public Services International (PSI) and the International Transport Federation (ITF). The threat of international industrial action was also significant in pressuring the government to desist from implementing repressive legislation against union activity in the public sector (FPSA, Annual Report 1989, p.41-2).

The administration's perception of trade unions as a threat was brought home in statements by Taniela Veitata, the former trade unionist turned Minister for Employment and Industrial Relations, when he described international union concern with labour matters in Fiji as tantamount to "war" (Fiji Times, 2 May 1989). A more sinister manifestation of this was in a military document submitted by army officers to Ratu Sir Kamisese Mara on 28 May 1989. This attacked, among others, trade unionists, claiming that Chaudhry's threat of a national strike against the Government's non- restoration of pay increments was an example of a politically motivated move to challenge the Government. The document also raised the Communist bogey supposedly lurking behind international trade union links, and proposed its own solution:

\footnotetext{
We believe that the threat of further Trade Union strike action can be effectively countered by abolishing the Trade Union Movement in Fiji and establishing a government agency within the Ministry of Labour to look after the interest of all the workers. 2
}

Apparently Veitata had been consulted on labour matters by the writers of this document.

The FPSA and Chaudhry's role in the Fiji labour movement has also been strengthened following a split in the FTUC which led to Chaudhry's election as general secretary of the Congress in January 1988. Along with other new appointments, this led to the FTUC adopting a somewhat more aggressive and critical stand during the past two years and extending its educational, training and other programmes (FTUC, 1989). Chaudhry is also general secretary of the National Farmers' Union which is refusing to cut cane during 1990. The administration is implying that their non- acceptance of an unsatisfactory sugar award and Chaudhry's threats of international bans on Fijian sugar exports is a plot to topple the regime (Fiji Times, 11 June 1990).

Unions have represented a significant source of opposition to a government which came to power behind the gun and will consolidate this through implementing discriminatory legislation to disenfranchise many Fijian citizens. As Munck notes (1988, p.176), although labour unrest may not always be the direct cause of military intervention, it is usually a significant underlying element. Certainly the Fijian regime has blamed labour and the unions for precipitating the coups and for post-coup economic hardship. ${ }^{3}$

In practice, however, there has been little concrete evidence of unions taking militant action to destabilize the regime. Words have been their main weapon and Chaudhry continued, as before the coup, to be the principal unionist publicly attacking a wide range of policies and practices, particularly in the public sector. He questioned the accountability of public finances, the transfer of resources from social services to the

2 Copy of army document to Ratu Mara, 28 May 1989.

3 Correspondence from Colin Clark, General Secretary, New Zealand Public Service Association, to Veitata, 4 August 1989, in reply to letter from Veitata, 25 May 1989 (NZPSA files). 
military, and drew attention to the "unprecedented exploitation of workers" not only in the public sector but especially in the private sector. The regime's development policies, such as promoting the establishment of Export Processing Zones were also strongly criticized as workers there still face extremely low wages and inadequate conditions (FPSA, Annual Report, 1988, p.13). Tomasi Vakatora, the acting Minister for Trade and Commerce demanded that appropriate action be taken against Chaudhry for spreading publicity about conditions in the garment industry which was "sabotaging the economic recovery of the country" (Fiji Times, 31 May 1988).

Fundamentally the "danger" posed by many trade unions comes from their commitment to the restoration of democracy. Chaudhry has repeatedly stated that the free operation of trade unions depends upon the political context they operate within. This has focused on the future constitution of Fiji. Because unions see this as a legitimate concern and have criticized proposals to restrict democratic rights, their existence provides a base which can question not only the administration's labour policies but the principles it rests upon. Chaudhry reported to an International Confederation of Free Trade Unions (ICFTU) executive meeting that: "without a constitution which embodies the principles of equality, justice and democracy, trade unions in Fiji will be unable to genuinely protect the interests of those it seeks to represent" (Fiji Times, 28 December 1988).

\section{Coercion}

\section{Direct coercion}

The most pressure put on unions since the coup has been through the threat and use of physical force. This was by no means new but circumstances in 1987 gave another dimension to direct coercion as a means to control trade unions. The burgeoning militarization of the State (Robertson and Tamanisau, 1989) greatly increased the potential for direct force. During the period when the sight of soldiers, guns and roadblocks was commonplace and when civil liberties and human rights were curtailed, abuses against trade unionists were common. Few trade union leaders in 1987 had any experience of direct militant action and had never openly threatened the regime with violence. The biggest weapon they had was to mobilize international solidarity. Partly to inhibit this and also to intimidate workers from participating in pro-democracy activities, the military regime resorted to physically harassing trade union officials and directly prohibiting them from engaging in a wide range of activities.

The most immediate direct constraint on trade union activities was when 5 union officials were delivered at gunpoint notices of suspension by the Civil Aviation Authority of Fiji (CAAF) in May 1987. This was on the grounds that the officials constituted security risks but it is now more probable that the following comments made in an unsigned letter to D.P. Singh, the president of the FPSA, were closer to the truth:

It is clearly victimisation of Union Official and activities, bringing in personalities. Check the Madhoji Report. Whatever name you find in there as a Union witness, you will also find in the suspended list. Whoever was active in Union matters, His name is in the suspended list. ${ }^{4}$

The suspension of these officials also severely affected the ability of the FPSA to take industrial action in this sensitive sector of the public service. The treasurer of the Nadi branch reported to Chaudhry in July 1987 that it was difficult to keep membership united with the detention of union colleagues. 5 Not surprisingly, Chaudhry concluded in 
the FPSA's 1987 Annual Report that the suspension and dismissal of their officials at CAAF was a result of CAAF management actively conspiring with military authorities to curb union activities at Fiji's airports. The FPSA's attempt to report this as a trade dispute on the grounds of a breach of the collective agreement, although initially accepted, was subsequently rejected by the Labour Ministry. The Ministry was taking orders from Rabuka, Minister of Home Affairs, who claimed that national and security interests dictated that the dismissal should not be treated as an employer-employee dispute and could not be covered by the Trade Disputes Act. ${ }^{6}$ After extensive internal and external pressure, and with a more conciliatory style of industrial relations introduced into CAAF, the suspended employees were reinstated by mid-1988. They were never found guilty of being security risks.

Intimidation and harassment of trade union officials stepped up while international sanctions persisted and also once the movement to restore democracy gathered momentum. Six FTUC executive members were arrested the evening prior to the 6 June 1987 FTUC meeting over the lifting of bans. This served to deter many members from attending, as did the arrival of Veitata, a prominent Taukeist and general secretary of the Fiji Registered Port Workers' Union. He was accompanied by several of his supporters and military observers. Participants at the FTUC meeting on 4 July also suggest that Veitata and 3 other unionists were instrumental in the FTUC decision to have international bans lifted through harassing and warning FTUC members of the consequences of supporting continued sanctions (also reported in Howard, 1988, p.200).

The second military coup of 25 September 1987 enabled the military regime and the PSC to take even more authoritarian measures to curtail the effectiveness of the labour movement in Fiji. Many trade unionists were among the approximately 350 coalition activists and supporters who were detained, while it is claimed at least 12 union leaders were assaulted and tortured (FPSA, Annual Report, 1987 p.11). The FPSA, Fiji Public Service Credit Union and FTUC offices were occupied and searched by the military for 3 weeks during October 1987. Following an arson attack on its offices, the FTUC lost several records and was forced to curtail many of its planned activities. Draconian legislation in the form of the Fundamental Freedoms Decree (No. 12 (14):Gazette 1(7), 13 October 1987) gave the military arbitrary powers to deprive people of basic human rights, such as freedom of movement and expression, and protection from arbitrary arrest and detention. Strikes and all other forms of industrial action were forbidden until this provision was lifted following the threat of international trade union action. During this period it was difficult for unions to hold meetings as they, like everyone else in Fiji required a permit from the police to hold a public meeting. This applied for example to a private national council meeting convened to discuss cost cutting proposals for the civil service.

Written permission was required for civil servants travelling overseas, while at least 120 trade union activists were placed on a military blacklist prohibiting overseas travel (FPSA, Annual Report, 1987, p.11-13). Although Chaudhry obtained clearance to attend the ITF-Asian Pacific regional conference in Tokyo in 1987, Veitata, the Minister for Employment and Industrial Relations assured Rabuka that he would "advise Mr Chaudhry of the consequences should he decide to spread adverse rumours overseas".7

Militarization of key essential services meant that not only did trade union activists face intimidation but the presence of force restricted the working activities of other employees. For example, on the night of 8 August 1987 a customs officer who attempted to ask a passenger why he was not complying with customs formalities, was assaulted by a military officer. In protesting against this to the Secretary of the PSC,

6 Correspondence from M T Vakatale, Acting Permanent Secretary, Employment and Industrial Relations, to General Secretary, FPSA, 8 January 1988 (36/K/98/87, FPSA, Suva).

7 Memorandum from Veitata to Rabuka, 20 November 1987 (ML 2/2-1, FPSA, Suva). 
Chaudhry emphasized the frequency of army officers intimidating FPSA members and interfering in customs work: "My Association registers its strong condemnation of these unlawful, dictatorial and violent acts".8

The FPSA also objected to military control in Fiji's ports. This was channelled through the Port Security Unit, which stepped up its prominence after the discovery of an arms shipment to Fiji in September 1988. Management at the Ports Authority of Fiji (PAF), including the director general were comprised of commissioned officers. Sometimes this conflicted with union loyalties, as when Lasarusa Tuimanu, a vicepresident of the FPSA resigned after being promoted to PAF management and becoming a commissioned officer. An FPSA report to the International Transport Federation in February 1989 suggested that PAF management were biased towards the dockworkers' union, the Fiji Registered Port Workers' Union. This is not surprising as its former general secretary was Taniela Veitata, the Minister of Employment and Industrial Relations, while the current secretary is a military officer. The militarization of port services has strengthened the role of his old union, with its members and those of the Port Security Unit pushing FPSA members out of duties covered by the collective agreement. The FPSA considers that "PAF is effectively using the union bashing technique of divide and rule", particularly as PAF had been one of the strongholds of FPSA support.

In another report to the PTTI (Asian and Pacific Regional Conference, November 1988) the FPSA stressed that the illegal shipment of arms had been used as an excuse to harass and detain trade unionists and political activists after the Internal Security Decree was imposed in June 1988 and backdated to March 1988 (Fiji Public Gazette: 2(39), 17 June 1988). This permitted the Minister of Home Affairs to detain for up to 2 years any person suspected of acting against the national interest of Fiji. Other powers given to the Minister included control over censorship of the media, freedom of speech and association and total control of individual liberty including the right to exclude persons from Fiji. As national interests include essential services, it exposed trade union leaders and members in these sectors to the risk of arrest, search of premises and detention.

Under this decree Chaudhry was again arrested and detained, while the military searched his office. The same night the army raided the home of the general secretary of the Fiji Oil and Allied Workers Union and FTUC vice-president, Michael Columbus (Fiji Times, 11 June 1988). After being faced with internal and international pressure, the Internal Security Decree was suspended in November, but the threat of such coercive power being reactivated remains when there is no legitimate guarantee of human rights. 9 This was borne out in early 1989 when Rabuka threatened to reactivate the Internal Security Decrees if workers supported the FPSA and FTUC calls for a general strike (Fiji Times, 8 April 1989). A year later a civilian government ostensibly governed Fiji when Rabuka returned to the barracks, but he soon warned that the military would intervene if trade unionists attempted to destabilize the country by going on strike (Fiji Times, 23 January 1990) or if cane farmers refused to harvest cane (Fiji Times, 30 May 1990). Veitata's most recent warning to Chaudhry is ominous: "That should he persist in his illegal activities, he and his organization will face the strongest possible action of a future that both are unlikely to win" (Fiji Times, 13 June 1990).

\section{"Legal" coercion}

While the administration found that it met obstacles in sustaining trade union compliance based on physical coercion, it met fewer problems in imposing "legal" coercion on public sector workers. A crucial step was the promulgation of the Public Service Order which

8 File note, S108/1043, FPSA, Suva, 29 September 1987.

9 Correspondence from FPSA to PTTI, 26 April 1989 (S410, FPSA, Suva). 
revoked the Public Service Act, along with subsidiary legislation. This removed a number of key conditions of service which public sector unions had secured in previous years and indirectly eroded the protection unions could offer members. The new order cancelled appeals against appointments, promotions, transfers and gradings, while it also facilitated the arbitrary reduction of salaries by 15 percent in 1987 . New disciplinary offences were stipulated, including "any other offences specified by the Commission." While an earlier provision under the Public Service Regulations 1987 provided for the establishment of a Disciplinary Appeals Board, by mid-1989 the PSC had shelved this proposal (FPSA, Annual Report, 1989, p.26), which further strengthened the arbitrary role of the PSC. Relevant here is Decree 5 of 1987 under which many members of the PSC were appointed by the Commander and Head of State of the military government. With the public service decrees remaining in force, PSC members continued to exercise "the provisions of these decrees quite indiscriminately, the military appointees to the Service Commissions have wreaked (sic) havoc on the public service".10

The decree also promulgated drastic changes in the composition of the civil service which would affect FPSA membership. Although the 1970 Constitution provided for racial parity in the public sector, the 1987 decree insisted that at least 50 percent of all positions at all levels be filled by indigenous Fijians or Rotumans. Employees were also required to retire at 55 instead of the established 60 years. The following quotation circulated in CAAF by an anonymous writer exemplifies the paranoia about the power of the FPSA and the need for the PSC to weaken this:

The present civilian government through the Public Services Commission have constructively and systematically severed the tentacle hold of the FPSA through the new 1987 Public Services Act whilst the FPSA has endeavoured to use the media for local and overseas support and all part of the orchestrated effort to erode the Military power that is the security foundation of the present civilian government. 11

As several reports of the FPSA note, in practice, even regulations were unneccesary for those sympathetic to the administration, as they used "favouritism and cronyism" to confirm promotions and appointments 12 (see also FPSA, Annual Report, 1989).

Although assuring international unions that it would protect human and trade union rights, the Fiji administration never relented in its attempt to control public sector unions. In April 1989 the Government announced its intention to amend legislation in order to prevent several categories of workers from joining trade unions and also to severely restrict the right to strike of fire-officers, forest guards, workers classified as managers, or dealing with confidential matters. Ultimately it would be up to the secretary of the PSC to designate a post as falling within one of these categories. A further drastic curtailment to industrial action was the classification of all sectors of the civil service as essential services, meaning that 28 days strike notice would have to be given.

The latest infringements on trade union rights drew strong condemnation from both the FPSA and international trade union bodies. To justify its action the Fiji Government misinterpreted International Labour Organization (ILO) conventions:

The recent amendments to the trade union laws were based on ILO Convention 98 , which bars public servants from forming trade unions and, ILO Convention 151 , which allows only certain levels of public servants to be unionized.13

10 Fiji Country Report to PTTI Regional Conference, FPSA, Suva, 14 November 1988.

11 Correspondence from anonymous writer, 5 February 1988 (S113/2/2388, FPSA, Suva).

12 Correspondence from FPSA to PTTI, 26 April 1989 (S410, FPSA, Suva).

13 Correspondence from Prime Minister's office to PSI and NZPSA, 25 May 1989 (S402, FPSA, Suva). 
However this contravenes the 116th Report of the ILO Freedom of Association Committee which concluded that although Convention 98 may permit (not bar) the exclusion of public servants engaged in the administration of the State, a ruling of the Committee of Experts states "that the exclusion from the scope of the Convention of persons employed by the State or in the public sector who do not act as agents of the Public Authority is contrary to the meaning of the Convention." This means that the distinction is between civil servants employed in various capacities in government ministries and other persons employed by the government. The Committee of Experts has also decided that Convention 151 does not overrule the articles of Convention 87, (Freedom of Association and Protection of the Right to Organize, 1948) in respect of the public service. According to the 181st report of the Freedom of Association Committee, the standards in Convention 87 apply to workers "without distinction whatsoever" and are applicable to employees of the State14 (also see ILO, 1988).

In its attempt to weaken the Fiji labour movement, the Fiji Government also warned the PSI and the New Zealand Public Service Association (NZPSA) that any further international trade union action would be construed as interfering in Fiji's sovereignty. This did not deter Colin Clark from the NZPSA reiterating to Veitata that his union would continue to be guided by unionists in Fiji. 15 Hans Engelbert, general secretary of the PSI, wamed that he could pull strings at a higher level:

Your country's membership of the ILO and our recognition under the ILO Constitution allow us to take such initiative to protect the rights of our affiliates and this we shall certainly continue to do in any part of the world where the trade union rights of our members are threatened.

He warned that the PSI could apply pressure through United Nations organizations and the resources of PSI's membership in nearly 70 nations. The outcome was that the international trade union secretariats advised affiliates to protest to the Fiji administration. Although the April 1989 amendments were shelved, they could still be implemented without notice.

While the threat of military intervention, detention and other coercive measures were activated to stamp out trade union activities, in the longer term the direct threat to trade union rights in the public sector came from regulations and the threat of reactivating more coercive ones. Surveillance of these moves by unions both within and outside Fiji has been able to counteract the severity of some of the draconian measures. If not for the persistence of the FPSA and the influence it has within the FTUC, then the passing of time may have led to an acceptance of these infringements, similar to much of the Fiji public's resignation to living under a military backed regime.

\section{Victimization}

The FPSA has also been unrelenting in fighting what it identifies as cases of victimization of union officials and members even when the industrial relations machinery in the public sector has made it extremely difficult to seek redress. The scope for victimization has increased greatly in the post-coup atmosphere, where "bullyism" can range from physical threats, to blocked transfers, promotions, re-grading, unclear or constantly changing job descriptions (so that an officer can not perform duties adequately) to the threat of disciplinary action. This has been given an enlarged potential when no appeals machinery exists. For example after being suspended and then reinstated in

14 Correspondence from PSI to Prime Minister's Office, 3 August 1989 (HE/HLB/AG-0892, FPSA, Suva).

15 Correspondence from Clark to Veitata, 4 August 1989 (ORGV1, NZPSA, Wellington). 
employment with CAAF in 1987, Muthu Swamy, the President of Labasa branch was given notice of transfer to Suva. Chaudhry considered this to be victimization of a union official but the only recourse was to take legal action (FPSA National Council minutes, 10 September 1988). Since the coup FPSA members and officials in Savusavu (a small town on the island of Vanua Levu) have reported being harassed by senior departmental officers but when resistance was shown, the branch president, Aisea Baitisaresare was transferred to Navua on Viti Levu (FPSA National Council Minutes, 18 August 1989).

Victimization against union supporters was by no means new in the public service in Fiji or elsewhere (Bain, 1970, p.132-33). As FPSA records indicate, there were several instances of members being wrongly disciplined, forced into early retirement, facing unacceptable transfers either to another task (which could be more onerous, of less responsibility or more isolating) or to a remote part of Fiji. The 1986 Madhoji Report is replete with claims of victimization in CAAF, which is partly why this report was not released until the Coalition assumed power. As outlined in a general survey of the Customs and Excise Department in 1986-87, victimization also operated through positive discrimination in favour of those who supported their superiors. These bureaucratic patrons might offer for example, appointments, promotions, or leave to attend educational courses. Such favouritism had much greater scope after the coups. Conversely, the same report noted that junior officers could be made to do the work of senior officers because the Principal Collectors had certain officers blacklisted because of union activity or personality clashes.

Fear of victimization did have an impact on dampening members' overt support for the FPSA and as union officials noted, this tactic of union control made it difficult to recruit and keep liaison officers and branch officials (FPSA, Annual Report, 1987, p.16; National Council Minutes, 10 October, 1988). It was also a factor behind the poor attendance noted at branch meetings, as in these smaller communities it was easier to identify people's political sympathies. Life could also become intolerable for those being constantly harassed, especially where there was no network of sympathetic colleagues. For example, Chaudhry had contemplated closing the Labasa branch as its officials had been ineffective since the coups. This was attributed to fear of victimization by their employer.

\section{Industrial relations practices and union control}

Some of the above forms of exerting coercion over labour are outside any formal industrial relations machinery. Other methods of control have been heightened by the removal or non-operation of established industrial relations practices, particularly in the public sector. There are still a number of instances where the Fiji regime, principally through the PSC, has utilized the industrial relations machinery in an attempt to weaken strong union representation. This suggests that institutionalized industrial relations may serve as a means of controlling potential labour unrest (Carter, 1985, p.165-67).

As noted, the Tripartite Forum initially appeared to offer a structure through which labour, employers and the State could resolve a number of industrial relations issues. Once the State dispensed with the Forum to negotiate wage guidelines, by imposing a unilateral wage and salary freeze in November 1984, tripartism ceased to be a comerstone of Fiji's industrial relations system. Instead, by 1986 the State held annual National Economic Summits, which, among other matters, discussed wage policies. Although union representatives were invited, as the summit included participants from a wide range of community organizations, this can be seen as a move to dissipate the role of unions. 
In 1989 Ratu Mara admitted that plans were underway to broaden the representation of the summit so that it might replace the Tripartite Forum. 16

A major impact on industrial relations since the coup has been the virtual abeyance of established dispute and negotiating machinery. The avoidance of these established practices is a further way of rendering unions ineffectual. In short, the FPSA and other unions are ignored as legitimate worker representatives when it suits the administration. The FPSA has noted that since the coup, employers have exacerbated the already entrenched practice of making their own interpretation of collective agreements and of breaching their provisions. In early 1988, the general secretary reported "widespread breaches of collective agreements in almost every statutory body. Employers have taken undue advantage of the current political and economic conditions, using it as a weapon to reduce employment conditions of their employees" (FPSA, Annual Report, 1988, p.31).

The FPSA still tried to register these clear breaches of collective agreements as disputes with the Permanent Secretary of Employment and Industrial Relations, but a number of means have been used to avoid settling these. Many reported disputes have been rejected on the grounds that management has acted in accordance with government directives. This occured when the FPSA was blocked in registering a dispute over the suspension of members at CAAF, due to directions from the PSC or from Rabuka. Here, a matter which unions perceived as within their legitimate sphere of concern was deemed as falling within "national security" and therefore exempt from established dispute settling procedures. Alternatively the Ministry of Labour may use stalling tactics to defer taking further action or reaching a decision. This has been a favoured tactic of management in the past, especially by the PSC. Other ways of avoiding negotiation and settlement have been the outright refusal by the Permanent Secretary of Employment and Industrial Relations to stipulate why a dispute has not been accepted, as when he refused to send parties in a National Marketing Authority dispute to arbitration (FPSA, Annual Report, 1988, p.20).

What steps can unions take, especially with the demise of the Tripartite Forum? Legal action is an avenue which the FPSA has repeatedly explored since the coup. Even this was impossible when the judiciary was suspended for a brief period after the second coup. Resorting to the judiciary process is also cumbersome and time-consuming, especially in a country which has a greatly understaffed and pressured court system. It is also extremely costly, and while a large union such as the FPSA may have the financial resources to take legal action, this is not an option for smaller unions or those whose members can not afford to contribute high union dues. Frustration at being hamstrung in working through the usual industrial disputes machinery has also precipitated the FPSA into gaining its members' mandate to take industrial action.

Consultative machinery has been a special feature of labour relations in the public sector. The Central Whitely Council, introduced in 1966 mainly to deal with staff relations, was later reconstituted as the Joint Consultative Council. This body has not met since August 1987 and is unlikely to be revived. Alternative joint negotiations by staff associations have been dissipated through the PSC holding separate meetings with them. Individual employees cases only are discussed while policy matters are arbitrarily decided by the Commission. FPSA officials have also been frustrated by the confrontational and rigid stance taken by PSC representatives in monthly meetings. Union delegates have found that this gave little scope for genuine dialogue as PSC officials appeared to have been given a fixed mandate from which to argue. The same obstructions seemed to hinder any headway being reached in conciliation meetings ${ }^{17}$ (see also FPSA, Annual Report, 1988, p.20).

16 Correspondence from Lavinia Ah Koy, Cabinet Secretary to PSI, 25 May 1989 (S402/288, FPSA, Suva).

17 Correspondence from General Secretary, FPSA to chair, PSC, 3 October 1988 (S224/838, FPSA, Suva). 
Obstructions also came from Aminiasi Katonivualiku, the Registrar of Trade Unions in accepting the registration of some new unions, such as the Fiji Mineworkers Union (Fiji Times, 11 January 1990) and in registering amendments to trade union constitutions. By early 1989 the Registrar had still not responded to an amendment submitted by the FPSA a year earlier to recruit members from the National Trust of Fiji (FPSA, Annual Report, 1988, p.31). Similar intransigence had been a problem in past attempts by the FPSA to amend its constitution, especially after controversial changes voted in 1986 (FPSA, Annual Report, 1987, p.27). There have been fewer hurdles for the registration of some recent ethnically based unions, including the Viti Civil Servants Association (VCSA) and the Fiji Air Traffic Controllers Association (FATCOA). This was in spite of protests from existing unions that the Registrar is not impartial, as these new unions are contravening the Trade Union Act. FATCOA's 28 members were all former members of the FPSA while by early 1990, 7 of its members were still members of the FPSA. Despite FPSA's insistence that FATCOA was encroaching on areas and categories served by the FPSA, it was still registered as a trade union.18 Like many developing countries, the Registrar of Trade Unions in Fiji, plays a pivotal role in the regulation of a compliant union movement (Bean, 1985, p.217).

\section{Ethnicity and splinter groups}

Employers and the State, generally did not often have to resort to coercion to exert control over labour organizations in Fiji. Encouraging the formation of splinter groups within workers' organizations has been a tactic repeatedly pursued by management. As noted, Fiji's colonial development, centred on the institutionalization of ethnic divisions between indigenous Fijians, Indo-Fijians and "others", has given a solid base upon which ethnic fractionalism has often been promoted by the State and other employers. The appeal to ethnicity as a means of dividing workers' organizations became more overt once demands for some kind of political representation were made by workers in Fiji (Durutalo, 1986).

Attempts by senior Fijian civil servants to fragment the FPSA along ethnic lines surfaced long before the political unrest in Fiji of the second half of the 1980s (Leckie, $1987 ; 1988)$. Ethnic ties which stressed loyalty to the chiefs and the State were drummed up whenever the civil service threatened or went ahead with industrial action. Communal tensions were again brought into play by a "concerned group" led by 10 ethnic Fijian members in 1986. Their platform was to purge politics from trade unions and the civil service but more specifically they sought to remove Chaudhry as General Secretary. This aimed to destroy the executive control held by the National Council and the secretariat's influence in the FPSA. The formation of a Suva branch would enable the "concerned group" to build up its own power base and be relatively autonomous from the National Council. Further plans included the withdrawal of the FPSA from the FTUC which would destroy one of the main cornerstones of the increasingly assertive union movement. This was particularly timely with widespread support by public sector workers for the recently formed FLP and with an impending general election.

Copies of documents of the "concerned group" suggest a more planned strategy, dating from the year before the coup, to destabilize the FPSA and much of the union support for the FLP. First, the legality of the 1986 annual general meeting of the FPSA was to be questioned so that it could be declared null and void; secondly, under "future development" were plans to "decentralise to four divisions" so that government would withdraw recogniton of the FPSA. Ethnic Fijian "contacts", many in senior bureaucratic positions, were also identified. A meeting with civil servants on 26 April 1986 in Nadi decided to form a breakaway Fiji Civil Servants' Association.

FPSA Report to ITF Asia/Pacific Civil Aviation seminar Goa, 10 January 1990. 
The rise of the Taukei movement during 1987 and its endorsement by the military regime, gave more open support by the authorities for the formation of a union to rival and possibly weaken the FPSA. On 9 July 1987 at the Fijian Teachers' Association building, members of the "concerned group" who had been expelled from the FPSA founded the Viti Civil Servants' Association. It emerged when the military regime and the PSC were trying to impose a 25 percent salary cut and other retrenchment measures on the civil service (Fiji Times, 7 July 1987). When the FPSA and other civil service unions threatened a nationwide strike, the PSC, in the wake of an ultimatum which threatened the redundancy of 12,000 officers, went ahead with the imposition of a 15 percent salary cut. Meanwhile the VCSA and the Public Employees' Union willingly acquiesced to pay cuts and proposed that civil servants give up other allowances they were entitled to (Fiji Times, 10 July 1987; 13 July 1987). Although it claimed political neutrality, a number of sources suggest that the VCSA was backed by senior members of the PSC. On 17 August 1987 a member wrote to Chaudhry concerning a group which was trying to destabilize the union: "It is very clear that P.S.C. staff have been asked from the top to divide the Association."19 Taniela Tabu, the secretary of the VCSA, was also a senior civil servant in the PSC and the official side secretary in the Joint Consultative Council. The interim president was the Permanent Secretary for Health, Dr Filimone Wainiqolo. As noted, the attitude of the PSC towards the civil service unions suggested that the PSC was coming under the direct control of the military regime. As well as encouraging splinter groups, the PSC was simultaneously encouraging management to promote the regime's policies by, for example, issuing circulars and having pocket meetings with staff. The identity of management with Fijian ethnicity and a hostile attitude towards the FPSA has also been facilitated by the "purge" of senior Indian civil servants from the civil service and attempts to introduce legislation prohibiting managers from being union members.

Since the VCSA proclaimed its loyalty to the regime (Fiji Times, 10 July 1987; 13 July 1987) it is not surprising that the union's registration was accepted. According to the Trade Union Act, any 7 persons may form a union but must then seek registration. This can be refused if another trade union is already registered and adequately representative of the whole, or a substantial proportion of the interests pertaining to those seeking registration of a new union. The VCSA, like other exclusively ethnic Fijian unions, justified their claims on the grounds that:

Under the Trade Union (Recognition) Act there is nothing to stop an employer from accepting racial grouping as a basis for recognition of a trade union if a racial group feels that a particular multi-racial grouping for trade union purposes does not protect their interests (Fiji Times, 4 May 1989).

To substantiate this, Tabu argued that trade unions had been monopolized by Indians because of their numerical domination of the workforce. Indian commitment to the labour movement was dismissed as manipulation to suit their own "racial needs" (Fiji Times, 4 May 1989). The PSC also overlooked a stipulation under the Trade Union (Recognition) Act that a union should represent 50 percent or more of the employees for whom recognition is sought when it formally recognized the VCSA (Fiji Times, 25 March 1988).

The bark of the VCSA has been bigger than its actual bite. Although its recruitment activities have been effective in trimming the membership of the FPSA, as elaborated below, the reduction in FPSA membership is not solely due to VCSA activities. Chaudhry has questioned Tabu's claims (Fiji Times, 28 April 1990) of having 1010 members in the VCSA. This included new civil service recruits, who were more likely to be ethnic Fijians or Rotumans and more susceptible to anti-FPSA propaganda. FPSA 
records also indicate that some newly recruited members of the VCSA have returned to the fold of the FPSA. Some of these "swinging" members have been opportunistic. They have joined the VCSA in the hope that this might facilitate promotions or other favours but have then rejoined the FPSA, especially once they realized that they might lose valued socio-economic benefits. FPSA attraction also lies in its greater experience and superior resources to fight individual as well as collective grievances.

Nevertheless, the VCSA still continued to be a thorn in the FPSA's side, with members being pressured to support government policies and the VCSA. Increased Taukei influence in management has also widened the scope for VCSA supporters victimizing FPSA members. At the very least, this means that FPSA members can be intimidated against criticizing the VCSA. The presence of a VCSA group in a department can also inhibit recruitment and overt support for the FPSA. At another level, the VCSA also operates as a propagandist of the administration and condemns criticism of policies directed at the public sector and its employees. They also staunchly endorse policies which advance the appointment and promotion of indigenous Fijians. The FPSA never questioned the necessity of this but has criticized the pace of indigenization, the discriminatory practices this leads to, and what are considered to be adverse effects on the quality of public services in Fiji. The VCSA has also clearly separated itself from the FPSA's approach to industrial action by passing resolutions at the 1989 and 1990 annual general meetings opposing national strikes and advocating the dismissal and replacment of civil servants taking part in any national strike (Fiji Times, 1 July 1989; 28 April 1990).

According to FPSA sources, the VCSA was responsible for circulating a number of malicious rumours, petitions and circulars to facilitate the easy withdrawal of groups of members from the FPSA. Chaudhry has questioned the authenticity of some of these signatures and suggested, for example, that defamatory statements and some of the 26 signatures of members in the Public Works department on a letter may have been the work of the VCSA. Their reasons for resignation were similar to those given in some bulk withdrawals from other departments:

\begin{abstract}
This is due to the fact that you have used the FPSA, to further your political interest, under the guise of Union Solidarity. Furthermore, your dictatorial and unscrupulous acts, deviates from democracy, but could be found behind the iron curtain. You should, after all practice what you preach. FARE THEE WELL COMRADE. 20
\end{abstract}

Rumours also helped the VCSA to form the Good Samaritan Credit Union. Supposedly, its rival, the Fiji Public Service Credit Union, had been misusing funds in early 1987 although it did announce record dividends during this period (Fiji Times, 6 February 1988).

Since the coup, there have been other attempts to form unions exclusively for Fijians, such as the Fijian Sugar Workers' Union (Fiji Times, 4 May 1989). Just as the VCSA was advised by the Fijian Teachers' Association, so the VCSA is keen to promote the formation of breakaway unions for ethnic Fijians. In opposition to the FTUC, the Viti Trades Union Council was set up by the FTA, Fijian Sugar Workers' Union, Native Land Trust Board Staff Association, Fijian Affairs Board Staff Association, Air Pacific Viti Employees' Union and Fijian Registered Port Workers' Union. Tabu saw these unions playing their part in busting any anticipated strikes and pledged that the VCSA would mobilize all Fijian workers by activating the Viti Trade Union Council if the FTUC went on strike. This declaration coincided with the FPSA serving a strike notice (Fiji Times, 28 April 1990) and the possibility that farmers would boycott the 1990 cane harvest. 
Appealing to ethnic ties has been a powerful tactic in promoting splinter groups from powerful trade unions such as the FPSA. Other rival groups encouraged by management do not necessarily cater to one ethnic group, although much of their support may come from indigenous Fijians. For example, CAAF recognized FATCOA, although FPSA had objected to its registration as a trade union. 21 Another rival union in the aviation industry has been dismissed by the FPSA's Nadi branch as solely aiming to fragment FPSA solidarity. 22

A further divisive tactic by the Government aimed at weakening trade union solidarity, especially within the public sector, has been to play upon differences between established and unestablished staff. This does not neatly correlate with perceived ethnic categories but has been tied in with attempts to stir up divisions between workers who have been categorized as "blue collar" and "white collar". Most of the unestablished staff in the public sector are "blue collar" and represented by the Public Employees' Union. There were several instances prior to the coup when the PEU accepted wage restrictions, through fear of redundancies (Leckie, 1988, p.158). In return, the PEU was supportive of the Alliance Government and have never called a strike. Their loyalty was assured after the coup when the PEU accepted pay-cuts and advised its members "to stay away from active politics. Any direct action now can only make matters worse and prolong the current crisis". 23

Other divisive forces had the potential to weaken trade unions in Fiji. These factions have been an interplay of internal and external pressures, sometimes playing upon ethnic loyalties, at other times reflecting attempts to stir up divisions between the so-called blue and white collar workers and private and public sector workers. Political affiliations may be an underlying motivation, as for example, when some trade unionists, such as Mahendra Sukhdeo, attempted to discredit the FLP in early 1987 by claiming it was dominated by the "white collar elitist" FTUC (Fiji Sun, 8 January 1987). After the coup, the FTUC came close to being severely ruptured by internal divisions. These sprang not only from Taukeist unionists but also from other long-standing, ideological and personal differences between executive members. A key issue centred on the pressure the FTUC would take against the regime, especially over the degree of industrial action that the FTUC would call for locally and internationally. When the president, Jale Toki, announced that the FTUC would shelve its threatened strike, he contradicted the views of several affiliates (Fiji Times, 13 June 1989; 14 June 1989). Toki's reluctance to keep the strike threat was shared by a recently formed Association of Private Sector Unions, led by FTUC officials deposed in early 1988, former Treasurer, Bob Kumar, and former General Secretary, James Raman (Fiji Times, 10 October 1988; 12 September 1988). This group pressed for the removal of several members of the FTUC management, especially Chaudhry, on the grounds that their political activities were adversely affecting the FTUC (Fiji Times, 6 June 1989). Chaudhry claimed that the Government's refusal to recognize the Congress and its attempts to send individual invitations to a National Economic Summit was a "government ploy to create divisions within the union movement" (Fiji Times, 12 June 1989).

Within the FPSA, executive members, Tupeni Tavutonivalu and Jese Ligari, publicly discredited Chaudhry's union duties and his affliation to the FLP (Fiji Times, 4 August 1989). Sources suggest that such internal rifts represent part of a strategy to turn the FPSA into a compliant puppet of the regime. These personal attacks were reiterated by Fijian members of the Board of Fire Commissioners of Suva when they filed a petition demanding the suspension of Chaudhry. This occured in a year which began with a strike and a go-slow by the Board's employees and led on to the FPSA challenging several management decisions (FPSA, Annual Report, 1988, p.36).

23 PEU Newsletter, 20 August 1987. 


\section{Membership levels}

How can we assess the impact of these moves to weaken trade unions, especially the FPSA in Fiji? Although threatened by physical coercion and hamstrung by repressive legislation, the FPSA has persisted in trying to pursue individual and collective grievances. Its leadership has also continued to be outspoken about wider issues in Fiji, especially those which affect the material welfare and political rights of workers. The fact that members and officials still report instances of victimization suggests that union members have not been silenced into complete submission. In 1989 members voted a 50 percent rise in union deductions, indicating their confidence in the management and activities of the FPSA. The increase in union dues also ensured a steady income necessary with rising inflation, and extra costs incurred for legal support and socioeconomic projects. Additional revenue has also been essential to counteract declining membership levels, particularly if the Association aims to maintain and expand the quality of its services.

The effects of attempts to weaken the union are shown in the dramatic falls in membership levels since the coup. As table 1 indicates, FPSA membership has fallen by 2552 , or 36 percent, between 1986 and 1989. Membership declines were higher in the civil service ( 37 percent) compared to statutory bodies ( 27 percent). Excluding statutory bodies, the civil service had, by early 1989,4492 FPSA members ( 77 percent) compared to 1341 non-members ( 23 percent). ${ }^{24}$ The drop for 1990 will be even greater if the association is unsuccessful in its bid to regain about 1053 members from the former Department of Posts and Telecommunications employed since January 1990 in the new company, Fiji Posts and Telecommunciations Limited. Like trends elsewhere, the privatization of public services in Fiji opens the way to changes in labour organizations, with the potential weakening and decentralization of strong encompassing unions.

Anti-FPSA elements have attributed the fall in membership to disenchantment with the union, but as noted, there have been a number of other factors, stemming from developments since the coups, which have contributed to membership loss. A principal factor has been the substantial number of resignations and retirements from the civil service since the coups. It is likely that most of these were union supporters. Many vacant posts have not been renewed or filled, as shown in the declining size of the civil service since 1987. The changing ethnic composition of the service (table 4), due to the high percentage of Indo-Fijians (72 percent) among those resigning or retiring (table 2), along with a marked increase of ethnic Fijians as new appointments (table 3), also had implications for the success of union recruitment. The FPSA still recruits many of these as new members, but there are greater setbacks in attracting appointees who may have developed anti-union prejudices during the past few years. Some may also perceive support of the FPSA to be "un-Fijian" and consequently be more responsive to overtures from the VCSA.

The activities of the VCSA have also encouraged block resignations of ethnic Fijians from the FPSA. Initially this was confined to departments where Fijian employees predominated, such as Public Works, Health and Primary Industries. Letters of resignation (which were often copies of one another) protested at the perceived political involvement of the association. Nevertheless, the FPSA's 1988 Annual Report revealed that while there had been a decline of 1113 compared to 1987 , that only 267 members (or 24 percent of those who had resigned) had left the FPSA but were still in service (FPSA. Annual Report, 1988, p.19) and not all of these necessarily joined another union. Around April 1989 there was a noticeable increase in individual resignations which included a rise among Indo-Fijians and females. Their letters stressed that because of financial hardship they could not meet the proposed increases in fees by the FPSA. 
Table 1: Membership levels of the FPSA 1986-89

\begin{tabular}{llll}
\hline Year & Civil Service & Statutory Bodies & Total \\
\hline 1986 & 6254 & 938 & 7192 \\
1987 & 5690 & 715 & 6405 \\
1988 & 4613 & 681 & 5294 \\
1989 & 3955 & 685 & 4640 \\
\hline
\end{tabular}

Source: FPSA membership files; Annual Reports 1986-89.

Table 2: Resignations and retirements from the Fiji civil service (by ethnic group)

\begin{tabular}{|c|c|c|c|c|c|c|c|c|}
\hline \multirow[b]{2}{*}{ Period } & \multicolumn{4}{|c|}{ Resignations } & \multicolumn{4}{|c|}{ Retirements } \\
\hline & Fijian $^{a}$ & Indian $\mathrm{b}$ & Otherc & Total & Fijian $^{a}$ & Indian $b$ & Otherc & Total \\
\hline July-Dec1987 & 25 & 187 & 30 & 242 & 56 & 194 & 2 & 252 \\
\hline Jan-Dec 1988 & 95 & 539 & 37 & 671 & 122 & 96 & 18 & 236 \\
\hline Jan-June1989 & 37 & 178 & 13 & 228 & 42 & 20 & 4 & 66 \\
\hline Total & 157 & 904 & 80 & 1141 & 220 & 310 & 24 & 554 \\
\hline $\begin{array}{l}\text { Total resignations } \\
\text { and retirements }\end{array}$ & 377 & 1214 & 104 & 1695 & & & & \\
\hline
\end{tabular}

Source: FPSA membership files; Annual Reports 1986-89.

Notes: a Ethnic Fijians.

b Indo-Fijians.

c Other ethnic groups.

Table 3: New appointments in the Fiji civil service (by ethnic group)

\begin{tabular}{lcccc}
\hline Period & Fijian $^{\mathrm{a}}$ & Indian & Otherc & Total \\
\hline $1 / 7 / 87-30 / 6 / 88$ & 534 & 196 & 100 & 830 \\
$1 / 7 / 87-1 / 6 / 89$ & 191 & 106 & 48 & 345 \\
Total & 725 & 302 & 148 & 1175 \\
\hline
\end{tabular}

Source: FPSA membership files; Annual Reports 1986-89.

Notes: a Ethnic Fijians.

b Indo-Fijians.

c Other ethnic groups. 
Table 4: Ethnic composition of the Fiji civil service

\begin{tabular}{|c|c|c|c|c|c|c|c|}
\hline \multirow[t]{2}{*}{ Period } & \multicolumn{2}{|c|}{ Fijian $^{a}$} & \multicolumn{2}{|c|}{ Indianb } & \multicolumn{2}{|c|}{ Otherc } & \multirow[t]{2}{*}{ Total } \\
\hline & no & percent & no & percent & no & percent & \\
\hline $1 / 5 / 87$ & 8067 & 46.8 & 8208 & 47.6 & 962 & 5.6 & 17237 \\
\hline $30 / 6 / 88$ & 8413 & 49.9 & 7621 & 44.6 & 928 & 5.5 & 16962 \\
\hline $31 / 5 / 89$ & 8648 & 53.0 & 7127 & 43.0 & 648 & 4.0 & 14423 \\
\hline $\begin{array}{l}\text { Compared } \\
\text { to } 1 / 5 / 87\end{array}$ & +581 & - & -1081 & & -214 & & \\
\hline
\end{tabular}

Source: FPSA membership files; Annual Reports 1986-89.

Notes: a Ethnic Fijians.

b Indo-Fijians.

c Other ethnic groups.

During 1989 resignations became more scattered throughout government departments and spread outside Suva. The most recent cause of further resignations has been from the privatization of Posts and Telecommunciations.

While the FPSA responded to this membership drop by invoking a membership drive, it faced further setbacks with management policies in mid-1989. Until then the Association monitored current and potential membership by having access to the monthly employment printout for the civil service. When this service was refused by the Permanent Secretary for Finance in August 1989, the FPSA suggested that this was because of a cabinet direction to protect the VCSA and not cooperate with the FPSA. ${ }^{25}$ Although the FPSA found alternative means to keep track of these records, such action has increased the workload of the union secretariat.

There have also been instances of management facilitating union withdrawals and wrongfully ceasing union deductions. According to the FPSA's constitution, members should individually submit a letter of resignation to the General Secretary. When, for example, the Permanent Secretary for Posts and Telecommunications was advised by Chaudhry that he had wrongfully stopped 135 members deductions ${ }^{26}$ he then provided staff with union withdrawal forms. These were on a circular which also thanked staff who had signed a petition to the FPSA calling for the lifting of trade bans against Fiji by overseas unions. Chaudhry described this as:

very provocative, it directly serves to undermine the unity and solidarity of members...Y Your decision and action to furnish such forms, whether intentionally or unintentionally is a direct attempt to weaken the Association because it encourages and facilitates membership withdrawal. 27

25 File S12/2339, FPSA, Suva, 17 August 1989.

26 Correspondence from FPSA to Permanent Secretary, Post and Telecommunications, 15 July 1987 (S12/1672, FPSA, Suva).

27 Correspondence from FPSA to Permanent Secretary, Post and Telecommunications, 5 August 1987 (S12/1709, FPSA, Suva). 


\section{Fighting back}

Falling membership numbers, along with other divisive tactics aimed at weakening the FPSA, have boosted moves by the union to reverse these trends. By late 1989, the FPSA embarked upon a membership drive which sought to dissuade members from resigning and to sign up non-members, especially new civil service recruits.

Another strategy to strengthen the union has been restructuring. There has been an effort to revive the role of liaison officers, the organizers at the office-floor level. While some branches such as Labasa appear to have been weakened by dissident elements, others, especially Nadi and Lautoka have been strengthened through the establishment of full-time secretariats since late 1988. A further move to encourage members' participation, has been the reactivation of the Women's Wing in early 1988 and proposals for a Youth Wing. Emphasis has also been given to strengthen union education and training courses within Fiji since 1988.

One of the most important drawcards for union membership, recently expanded by the FPSA, has been socio-economic benefits for its members. While pragmatically these are incentives to attract and retain members, these projects also grew from a conviction, ardently advocated by a former FPSA president, Bavadra, that unions should take a broader role than simply being concerned with workplace matters. Socio-economic schemes would play an educational role, both for members and as models of alternative structures for the wider public. The oldest scheme which is administered separately from the FPSA is the FPSA Credit Union, but its origins owe as much to the enthusiasm for credit cooperative schemes in Fiji than to any specific union ideology. A change in the direction of socio-economic projects, partly because of Bavadra's influence, developed in July 1988 with the establishment of Fiji's first union-controlled medical centre in Suva along with similar services for branch members and their families. Other union benefits include assistance for overseas medical treatment, a retirement benefit, a bereavement payment to spouses and housing assistance through the FPSA Investment Cooperative Association.

The membership and publicity drive, restructuring of the union and increased socioeconomic benefits have been some of the means by which the FPSA has tried to retain its membership. As this paper documents, the FPSA has counteracted attempts to weaken it and the Fiji labour movement through many other means. It has firmly maintained its assertive stand on the salaries and conditions of its members, personal and wider grievances, general conditions in the public service and trade union rights and issues affecting the general public. As far as possible, the FPSA has attempted to utilize established industrial practices although since the coup it has resorted to legal action to an unprecedented extent. While the breakdown of much of the industrial relations machinery has affected all unions in Fiji, the FPSA has faced specific obstacles in relation to its changed relationship with management and the especially the PSC. The style of the FPSA has generally been to keep channels open for dialogue and to threaten industrial action only when further discussions were delayed or blocked. While consultation between the FPSA and the PSC has been eroded since the coup, there have been positive improvements in labour relations in statutory bodies, especially within CAAF.

Given the restraints to negotiation, members at post-coup meetings have endorsed resorting to industrial action to restore salary levels and other conditions. This is not a radical departure from the past but does indicate that the association is determined not to be cowered into taking a submissive stance. In April 1990, the FPSA filed a 28 day strike notice in response to government's refusal to grant civil servants a 6 percent pay increase permitted to other workers in 1988 and to allow civil servants the 12 percent increase in allowances payable under a wage order issued in 1989. The strike notice was rejected by the Ministry of Employment and Industrial Relations on the grounds that there is a court case pending on the issue. Chaudhry kept the strike notice as he maintained that the Ministry and the PSC were in collusion as the court action was 
challenging the authority of the Ministry of Finance to impose regulatory wage increases and to frustrate provisions of a contract of employment. Striking was not resorted to, as the administration finally agreed to the pay increase (FPSA, Annual Report, 1989, p.1516; Fiji Times, 31 March 1990; 20 April 1990; 4 June 1990).

Partly because of the virtual impossibility of legally going on strike, the FPSA has retaliated to attacks on unions by taking the debate to a wider level. One of the biggest strengths it has is that its general secretary holds the same position with the FTUC. This has reinforced links which public sector unions have developed with external union and labour organizations. Ultimately this means that trade unions in Fiji can muster international solidarity and sanctions if pressed.

Trade bans are a last resort and international bodies are reluctant to take this step until all other avenues are exhausted. The International Confederation of Free Trade Unions (ICFTU), to which the FTUC is affiliated, has played a critical role in monitoring trade union rights and labour conditions in Fiji and in facilitating dialogue between the unions and government. An ICFTU mission to Fiji in October 1989 secured a statement of intent from the Economic Strategy Committee of Cabinet. This aimed to restore recognition of the FTUC as the sole representative body of unions and workers in Fiji, restore trade union rights, reactivate tripartite bodies and recognize ILO standards in future reviews of industrial laws and procedures (Pacific Unionist, 1989, p.1). To date, government has not implemented these agreements, which is reminiscent of the "false respectability" displayed by government in previous assurances given to the ICFTU.28 The regime's lack of commitment to agreements made with international labour bodies has been spelt out by recent threats to ban the ICFTU from Fiji (Fiji Times, 9 June 1990).

\section{Conclusion}

During the past 3 years, the regime in Fiji has given a taste of the lengths it is prepared to take to squash challenges to its hegemony. Labour-State relations are a far cry from the comparatively consultative style under tripartism during 1976-84. Even then, strains were becoming marked. The abandonment of tripartism, moves towards unilateral decisions by government and threats of bringing in the army pushed unions into seeking redress to economistic problems through political ends. Material issues were not the only ones, as unions, especially the FPSA, saw their legitimate concern to be corruption, State and management policies and after the coup, human and democratic rights.

What is the biggest threat to unions in Fiji today? This paper has documented manoeuvres to fragment unions, especially along ethnic lines. This had some impact on the FPSA but not as much as anti-union dissidents had wished. Changes in the labour market, the setting up of new industries in tax-free zones and the restructuring of government bodies will greatly weaken the labour movement unless it is able to adjust its own style to attract and maintain workers' support. The State has resorted to outright coercion and could ban unions but this might lead to the kind of international pressure even Fiji's ardent union-bashers wish to avoid. On the other hand, recent Taukei extremists saw the solution in creating a leadership vacuum by deporting some labour leaders, such as Chaudhry.

Unions, particularly the FPSA, have built up a strong base and have drawn upon years of experience to counter attacks directed at them after the coup. Throughout most of their history they have faced hostility and negative images, especially from the press. In 1985, many observers saw anti-unionism stemming from those with political control and realized that the labour movement would have to secure a political base if it was to 
avert a pattern of State-labour relations heading in the direction of Singapore where "unions would be tolerated but their power would be significantly curbed" (FPSA, Annual Report, 1987, p.12). Today, unions have lost their political base and the promulgation of a new constitution leaves little hope of operating within a sympathetic political context. Although the political constraints are being tightened, it is likely that further constraints will be placed upon the operations of trade unions in Fiji. The record has shown that after being blocked from seeking redress through the legal machinery or through the courts, when unions pull out their ultimate weapon, the threat of local or international industrial action, this is construed by their opponents as a politically engineered move to topple the regime. When unionists speak out about trade union rights or other inequalities then this is also labelled political (see letters to editor Fiji Times, 13 September 1988; 19 August 1988). In order to protect their members' interests, trade unions in Fiji are fighting for their survival but this is most unlikely to lead to a "deal" with Fiji's forseeable political leaders. Their survival and struggle is very much a political issue, particularly as they will have to operate within a political structure they have never endorsed, and are unlikely to endorse.

\section{References}

Unpublished sources: Unless otherwise indicated, files are from the FPSA. In some cases due to the sensitive nature of the material, direct sources may not be given.

Bain, A. (1985) Labour protest and control in the goldmining industry of Fiji, 19351970. South Pacific forum 3(1): 37-59.

Bain, A. (1988) A protective labour policy? An alternative interpretation of early colonial labour policy in Fiji. The journal of Pacific history 23(2): 119-136.

Bain, G.S. (1970) The growth of white-collar unionism. Oxford, Oxford University Press.

Bean, R. (1985) Comparative industrial relations. An introduction to cross-national perspectives. London, Croom Helm.

Carter, R. (1985) Capitalism, conflict and the middle class. London, Routledge and Kegan Paul.

Damachi, U.G., Seibel, H.D. and Trachman, L. (eds.) (1979) Industrial relations in Africa. London, Macmillan.

Davui (1989-90) (International Newsletter of the Movement for Democracy in Fiji).

Dean, E. and Ritova, S. (1988) Rabuka: no other way. Sydney, Doubleday.

Durutalo, S. (1985) The Fijian trade union movement at the crossroads. The journal of Pacific studies 11: 190-207. Reprint of paper presented to the FTUC workshop on social and political options for the labour movement in Fiji, Suva, 9 May 1985.

Durutalo, S. (1986) The paramountcy of Fijian interest and the politicisation of ethnicity. Suva, South Pacific forum Working Paper no. 6.

Fiji Public Service Association (1969-1989) Annual reports.

Fiji Public Service Association (1969-1989) National Council minutes.

Fiji Trades Union Congress (1989) The Fiji economy: Issues, constraints and social implications: for the National Economic Summit. June 29-30, 1989. Suva, FTUC.

Hagan, S. (1987) Race, politics and the coup in Fiji. Bulletin of concerned Asian scholars 19(4): 2-18. 
Hempenstall, P. and Rutherford, N. (1984) Protest and dissent in the colonial Pacific. Suva, Institute of Pacific Studies, University of the South Pacific.

Hince, K.W. (1971) Trade unionism in Fiji. Journal of industrial relations 13(4): 368389.

Hince, K.W. (1985) The earliest origins and suppression of trade unionism in the Fiji Islands. New Zealand journal of industrial relations 10(2): 93-101.

Howard, M.C. (1985) The evolution of industrial relations in Fiji and the reaction of public employees' unions to the current economic crisis. South Pacific forum 2(2): 119123.

Howard, M.C. (1988) Fiji after the first coup. South Pacific forum 4(2): 180-208.

International Confederation of Free Trade Unions (1988) Annual survey of violations of trade union rights 1988. Geneva, ICFTU.

International Labour Organization (1988) Joint Committee on the public service, Report 1, General Report. Geneva, ILO.

Lal, B. (1986) Politics in Fiji. Sydney, Allen and Unwin.

Lal, B. (1988) Power and prejudice: the making of the Fiji crises. Wellington, New Zealand Institute of International Affairs.

Leckie, J. (1986) The functioning of civil service unions during the colonial era in Fiji. South Pacific forum 3(1): 11-36.

Leckie, J. (1988) Confrontation with the State: Industrial conflict and the Fiji Public Service Association during the 1970s and 1980s. South Pacific forum 4(2): 137-179.

Leckie, J. (1991) Workers in colonial Fiji, 1870-1970. In C. Moore, J. Leckie and D. Munro (eds.) Labour in the South Pacific. Townsville, James Cook University of Northern Queensland Press.

Muir, J.D. and Brown, J.L. (1978) The changing role of government in collective bargaining. In E.M. Kassalow and U.G. Damachi (eds.) The role of trade unions in developing societies. Geneva, International Institute of Labour Studies.

Munck, R. (1988) The new international labour studies. An introduction. London, Zed.

Report of the board of inquiry into the state of industrial unrest prevailing between the Civil Aviation Authority of Fiji and the Fiji Public Service Association. Justice T. Mahhoji, 28 November 1986.

Robertson, R.T. and Tamanisau, A. (1988) Fiji: shattered coups. London, Pluto Press.

Robertson, R.T. and Tamanisau, A. (1989) Race, class and the military. Development and change 20: 203-234. 